\title{
VALIDATION OF THE ACETO-CARMINE TECHNIQUE FOR EVALUATING PHENOTYPIC SEX IN NILE TILAPIA (Oreochromis niloticus) FRY
}

\author{
VALIDAÇÃO DA TÉCNICA DO ACETO-CARMIM PARA AVALIAR O SEXO DE ALEVINOS \\ DE TILÁPIA NILÓTICA (Oreochromis niloticus).
}

\author{
Gustavo Javier Wassermann ${ }^{1}$ Luís Orlando Bertolla Afonso ${ }^{2}$
}

\section{SUMMARY}

\begin{abstract}
In this study a method for evaluating phenotypic sex in Nile tilapia was validated. A technique that uses aceto-carmine squash mounts to stain the entire gonadal tissue for microscopic examination (Method 2- squash mounts) was compared with a technique based on traditional histology. Approximately 2600 Nile tilapia fry weighing and measuring, respectively, between $0.25-2.50 \mathrm{~g}$ and $26-53 \mathrm{~mm}$, aged 35 to 60 days after hatch (DAH), were sexed using this methodology. In situ microscopic examination on the gonads was also performed. A reliable sexing using squash mount was possible with fish weighing more than 0.500g, 45-47 DAH. Results from microscopic observation using the aceto-carmine stain coincided $100 \%$ with the histological examination. Male gonadal tissue was characterized by the presence of cysts containing spermatogonia and spermatocytes, while females were easily identified by the presence of oocytes at the perinucleolar stage. The technique proved to be efficient not only in terms of evaluating sex proportion in fish but also because it allows immediate evaluation of gonadal sex and demands less time and labour.
\end{abstract}

Key words: sex evaluation, Nile tilapia.

RESUMO

Neste estudo foi validado um método para avaliar o sexo fenotípico de alevinos de tilápia nilótica. Foi comparada uma técnica que usa aceto-carmim para corar o tecido gonadal, $o$ qual é examinado em microscópio, com a histologia tradicional. Aproximadamente 2600 alevinos de tilápia nilótica com idade entre 35 e 60 dias após a eclosão (DAE), pesando e medindo, respectivamente, 0,250-2,50g and 26-53mm foram sexados usando este método. Foi também realizado um exame macroscópico das gonadas in situ. Foi possivel sexar com acerto, usando o método de aceto-carmim, alevinos com peso superior a 0.50g, 45-47 DAE. Os resultados das observações microscópicas usando o corante aceto-carmim coincidiram em $100 \%$ com o exame histológico. $O$ tecido gonadal dos machos foi caracterizado pela presenca de cistos que continham espermatogônias e espermatócitos, enquanto que as fêmeas foram facilmente identificadas pela presenca de ovócitos no estádio perinucleolar. A técnica provou ser eficiente não só para avaliar a proporção dos sexos, mas também porque permite avaliação imediata do sexo gonadal e demanda menos tempo e trabalho.

Palavras-chave: avaliação do sexo, tilápia nilótica.

\section{INTRODUCTION}

The Nile tilapia (Oreochromis niloticus) is one of the fish species most cultured around the world. The primary reasons that make the species suitable for aquaculture are resistance to diseases and tolerance to a wide range of environmental parameters, besides white meat with no internal spines. On the other hand, one of the main problems in culturing Nile tilapia is its precocious sexual maturity, which can be reached when fish weigh 20$30 \mathrm{~g}$ (4-5 months after hatching). Uncontrolled reproduction usually leads to crowded ponds and consequently reduced growth (VARADARAJ \& PANDIAN, 1987).

There are several ways of controlling reproduction in fish (DONALDSON et al., 1996). The most effective and widespread way of avoiding the undesirable reproduction in Nile tilapia is the culture of all-male populations, which is normally achieved through the administration of natural or synthetic steroid hormones (androgens) in the feed (PANDIAN \& SHEELA, 1995). The efficiency of this method depends on several factors (size and age of the fish, amount and type of hormone, period of

\footnotetext{
${ }^{1}$ Engenheiro Agrônomo, Mestre.

${ }^{2}$ Zootecnista, PhD., Department of Animal Science, School of Agronomy, Federal University of Rio Grande do Sul, Av. Bento Goncalves, 7712, Porto Alegre, RS, Brasil, 90540-000. E-mail: afonso@attcanada.ca. Author for correspondence.
} 
administration, etc) (SHELTON et al., 1981), which makes it difficult to produce $100 \%$ male populations. When masculinization is successful, the proportion of males may vary from $90-100 \%$.

Typically, grow-out fish farmers buy sexreversed Nile tilapia fry, presumed to be all-male, when they are 30-60 days old, weighing no more than $2 \mathrm{~g}$. However, in many cases after 4-5 months reproduction will start and fish will not grow to full market size.

Nile tilapia are sexually dimorphic, which allows sexing through examination of the genital papilla even when fish are small (AFONSO \& LEBOUTE, 1993). Generally, the efficiency of the sex reversal treatment is evaluated through histological analysis of the gonadal tissue or through the aceto-carmine squash method (GUERRERO \& SHELTON, 1974), the latter not yet validated for Nile tilapia.

In this study a protocol similar to that of GUERRERO \& SHELTON (1974) was validated, which is a simple, fast and effective method for sexing Nile tilapia fry. This protocol may serve as a tool either to speed up access to results in masculinization studies or to be used by fish producers to check the percentage of males when buying fry for stocking in grow-out ponds.

\section{METHODS}

Nile tilapia eggs were collected from females kept at the Aquaculture Laboratory of the Federal University of Rio Grande do Sul and incubated artificially (AFONSO et al., 1993). After swim up, fry were transferred to several $120 \ell$ plastic tanks and reared at water temperature of $27 \pm 1^{\circ} \mathrm{C}$. Approximately 2600 fry, from 20 to 60 days after hatch were sexed. Fish weight and length varied according to age from 0.25 to $2.0 \mathrm{~g}$ and $26 \mathrm{~mm}$ to $53 \mathrm{~mm}$, respectively, during this period.

The in situ macroscopic (Method 1) and squash mounted microscopic (Method 2) observations were compared and Method 2 was validated histologically. Before observations, fish were killed by cold shock (water temperature of $0^{\circ} \mathrm{C}$ ), weighed, measured, and dissected. For microscopic examination (Method 1) fish were cut ventrally, using a scalpel, from the genital papilla to the base of the pectoral fin. A window on the lateral side was opened and the viscera were removed, leaving gonads, swim bladder and kidneys in place. Once the pair of gonads was identified, a macroscopic observation based on the morphology, location, and insertion of the gonadal tissue was made. Then, a few drops of Bouin's solution were applied topically to the gonads. This procedure hardened the gonadal tissue facilitating its removal. After macroscopic examination the anterior and posterior ligaments were cut, and both gonads were removed using a forceps and placed on a glass slide. The aceto-carmine solution was prepared according to GUERRERO \& SHELTON (1974). Initially, 0.5g of indigo carmine was added to $100 \mathrm{~m} \ell$ of acetic acid (45\%) and boiled for 5 minutes. After cooling the solution was filtered, using filter paper and transferred to a dark bottle. Aceto-carmine solution was added and the tissue covered with a cover slip. Both gonads were then examined over their entire length under a compound microscope using magnifications of $100 \mathrm{x}$ and $400 \mathrm{x}$ (Method 2).

The gonads of 40 fish examined using methods 1 and 2, weighing between 0.50 and $1,50 \mathrm{~g}$, were submitted to histology. The tissue was fixed in Bouin's solution for 6 hours, dehydrated, embedded in paraffin, stained with haematoxylin and eosin and sectioned $(5 \mu \mathrm{m})$ transversely.

\section{RESULTS}

Once the viscera had been removed and the gonads exposed it was possible to make a macroscopic distinction between male and female gonads. The gonads of fish weighing 0.25 to $0.45 \mathrm{~g}$ could be located, but their macroscopic examination (Method 1) was difficult due to small size. Subsequent removal was hampered by tissue fragility, and microscopic observation on squash mounts was also difficult due to lack of cell differentiation. Reliable distinction between the sexes was possible with fish heavier than $0.50 \mathrm{~g}$. The external morphology of the gonads and their location and insertion in the abdominal cavity were useful observations for determining the gonadal sex using Method 1.

Male gonads were thin, translucent and located ventrally to the swim bladder, extending caudally from the head to the genital papilla. Figures $1 \mathrm{~A}$ and $1 \mathrm{C}$ show testicular tissue under a dissecting microscopic at different magnifications. Figures 1B and 1D demonstrate the same gonads after the addition of Bouin's solution. When Bouin's interacted with the testicular tissue it conferred firmness and integrity facilitating identification and removal of the gonads. Without prior addition of Bouin's male gonads were very difficult to remove due to their fragility, and tendency to form a tight coil once detached. After removing the gonads from the abdominal cavity and placing them on a glass slide we observed that the testes readily absorbed the stain solution and when in contact with it rolled up, despite prior Bouin's treatment. 


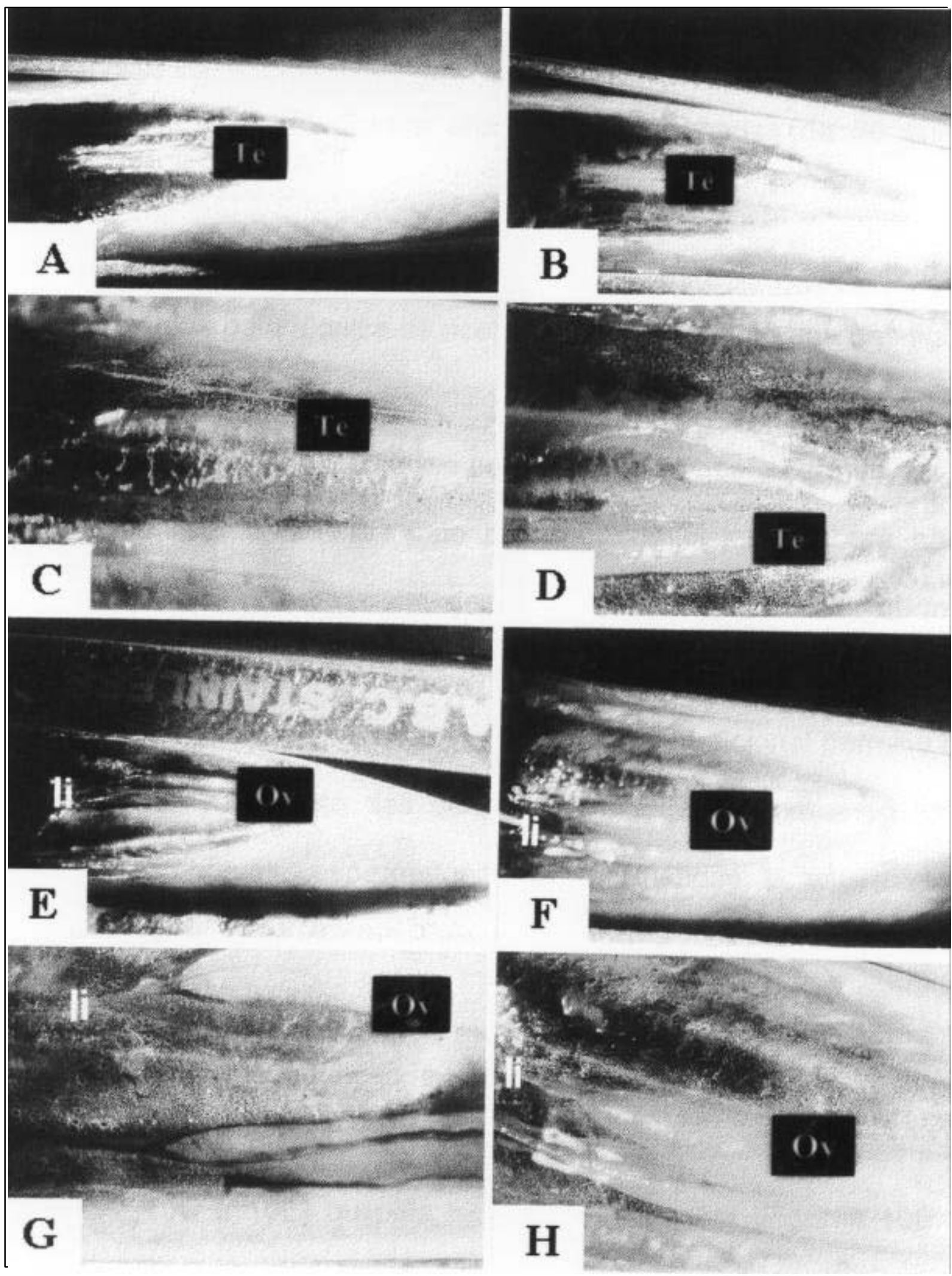

Figure 1 - Macroscopic examination of the testes (A,B,C and D) and ovaries (E, F, G and H) using magnifications of either 6x (A, B, E and F) or $15 \mathrm{x}(\mathrm{C}, \mathrm{D}, \mathrm{G}$ and $\mathrm{H})$, adding (B, D, F and H) or not ( A, C, E and G) Bouin's solution. Te, testis; li, ligaments; Ov, ovaries. 
Female gonads were thick opaque, had a round shape, and were also located on the ventral side of the swim bladder. However, the anterior part of the ovary was located more caudally than the testis and it was possible to identify the ligaments that held the tissue to the body wall (Figures $1 \mathrm{E}, 1 \mathrm{~F}$, $1 \mathrm{G}$ and $1 \mathrm{H})$. The ovarian tissue showed less affinity to the stain solution and in contrast to testicular tissue did not roll up when in contact with it. The results of the macroscopic examination (Method 1) coincided $100 \%$ with those from the microscopic sexing (Method 2).

To validate Method 2 for Nile tilapia we observed the gonads of the same fish (40 in total) under Method 2 and traditional histology. Figures $2 \mathrm{~A}, 2 \mathrm{C}$ and $2 \mathrm{E}$ show the gonads of 3 fish sexed by Method 2, while Figures 2B, 2D and 2F show the same tissue submitted to histological analysis.

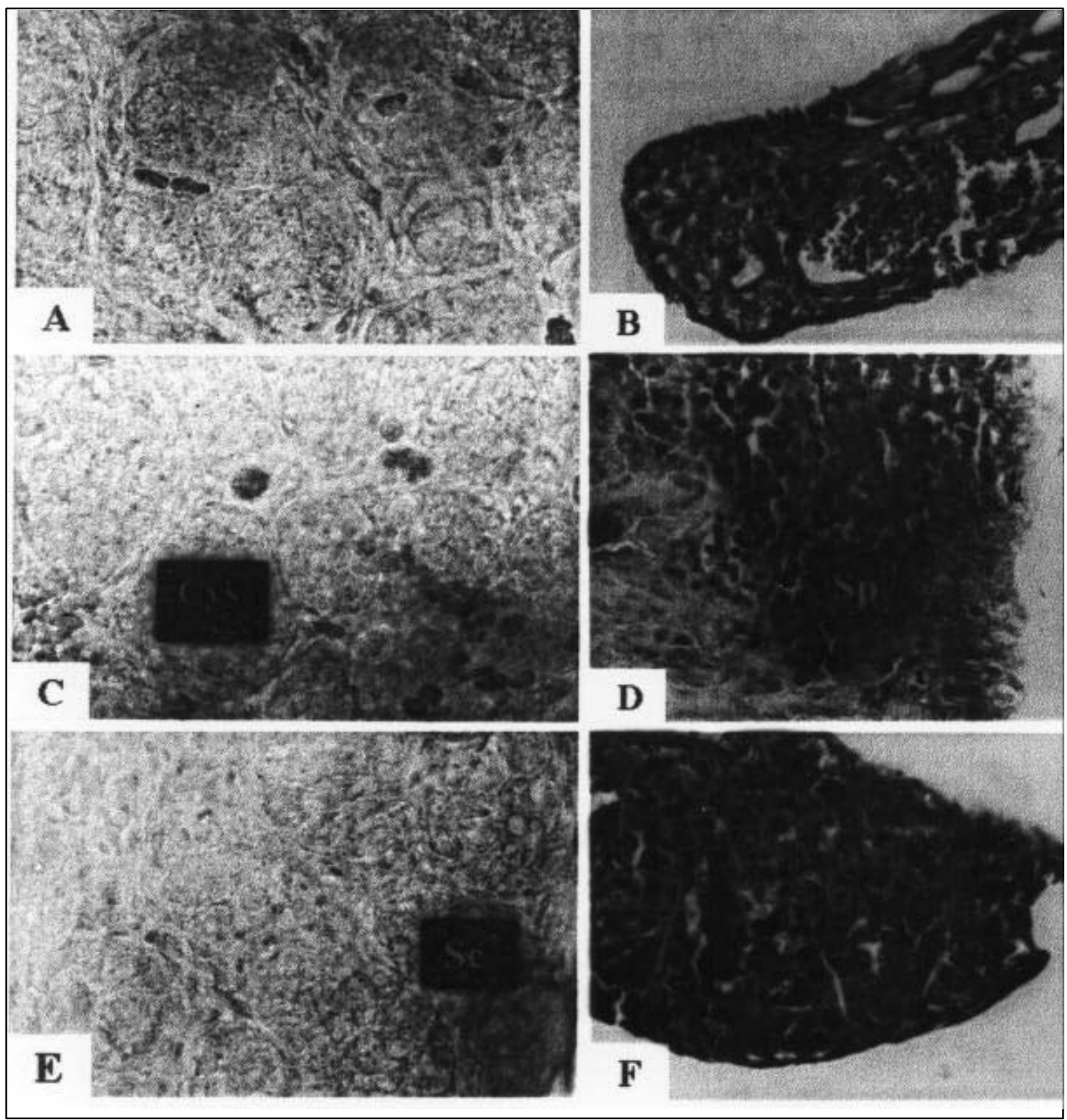

Figure 2 - Validation of the aceto-carmine stain technique for testicular tissue. A, C and E: testicular tissue stained with aceto-carmine. B, D and F: same testicular tissue under histology (400 x). Cys, cysts; Sc, spermatocytes;Sp: spermatogonia. 
Under Method 2 the gonadal tissue was defined as testis by the presence of cysts. Sometimes it was possible to identify the developmental stage of cells inside the cysts. Through histology, it was possible to define the stage of the cells on the testis, aalthough the cysts limits could not clearly be. On the other hand, in the ovaries it was possible to identify the same kind of structures by the two techniques (Method 2: Figures 3A, 3C and 3E; histology: 3B, 3D and 3F). Oocytes at the perinucleolar stage were observed. However the nucleoli were more clearly seen through histology. The definition of the gonadal sex of the 40 fish examined under Method 2 was confirmed by the histological examination.

When sexing fishes with the squash method were used the following criteria to define male and female gonadal tissue: presence of cyst-

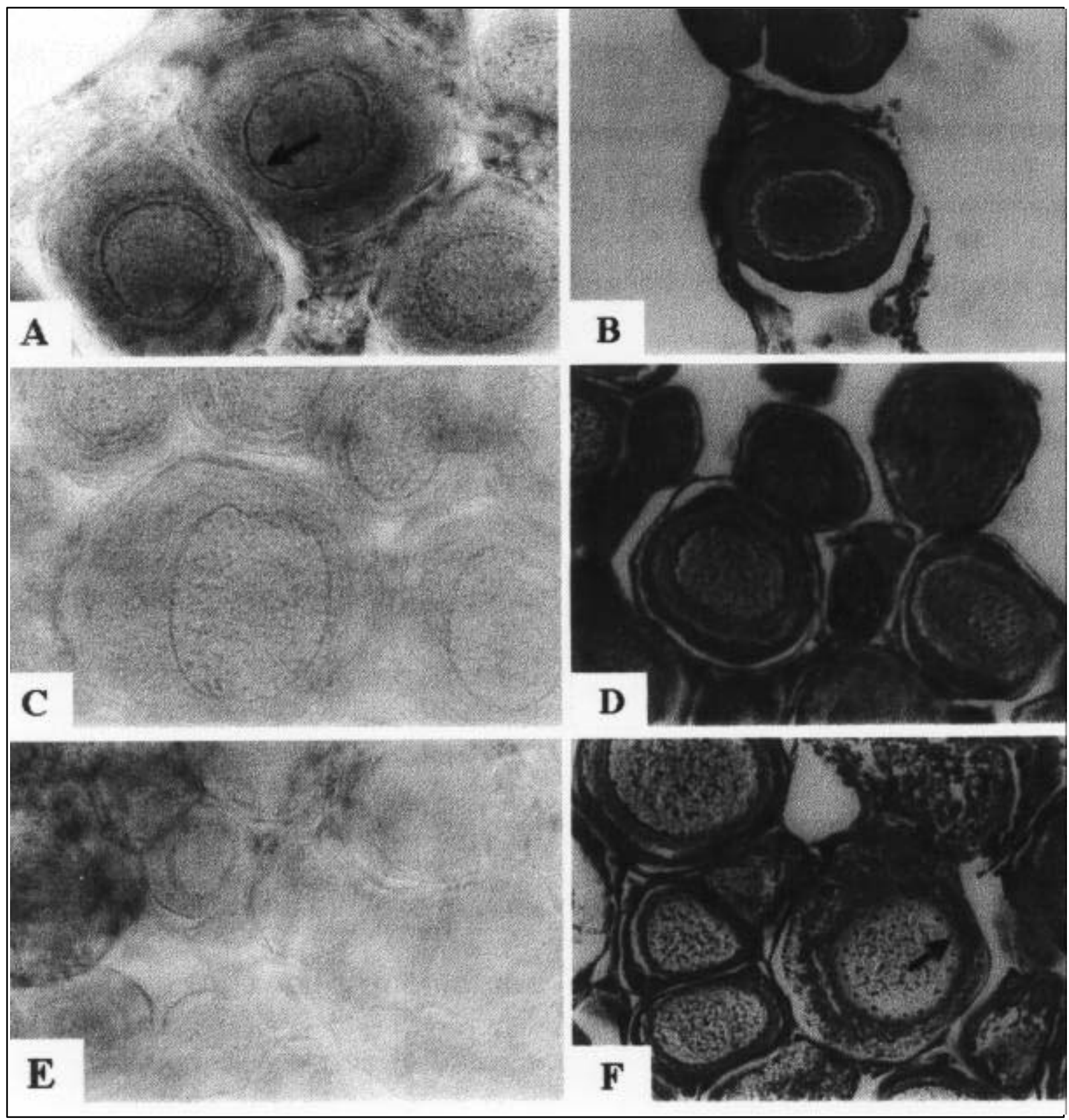

Figure 3 - Validation of the aceto-carmine stain technique for ovarian tissue. A, C and E: ovarian tissue stained with aceto-carmine. B, D and F: same ovarian tissue under histology $(400 \mathrm{x})$. In all cases it is possible to identify oocytes at the perinucleolar stage. Arrows indicate nucleoli. 
like structures containing spermatogonia and spermatocytes and appearance of oocytes at different stages of development. It is possible to differentiate clearly testes (Figure 4, A, C and E) from ovaries (Figure 4, B, D and F). At a magnification of $100 \mathrm{x}$ (Figure 4A) it was not possible to define the cell structure of the testis, although the cysts could be easily seen. On the other hand, at this magnification it waaaas
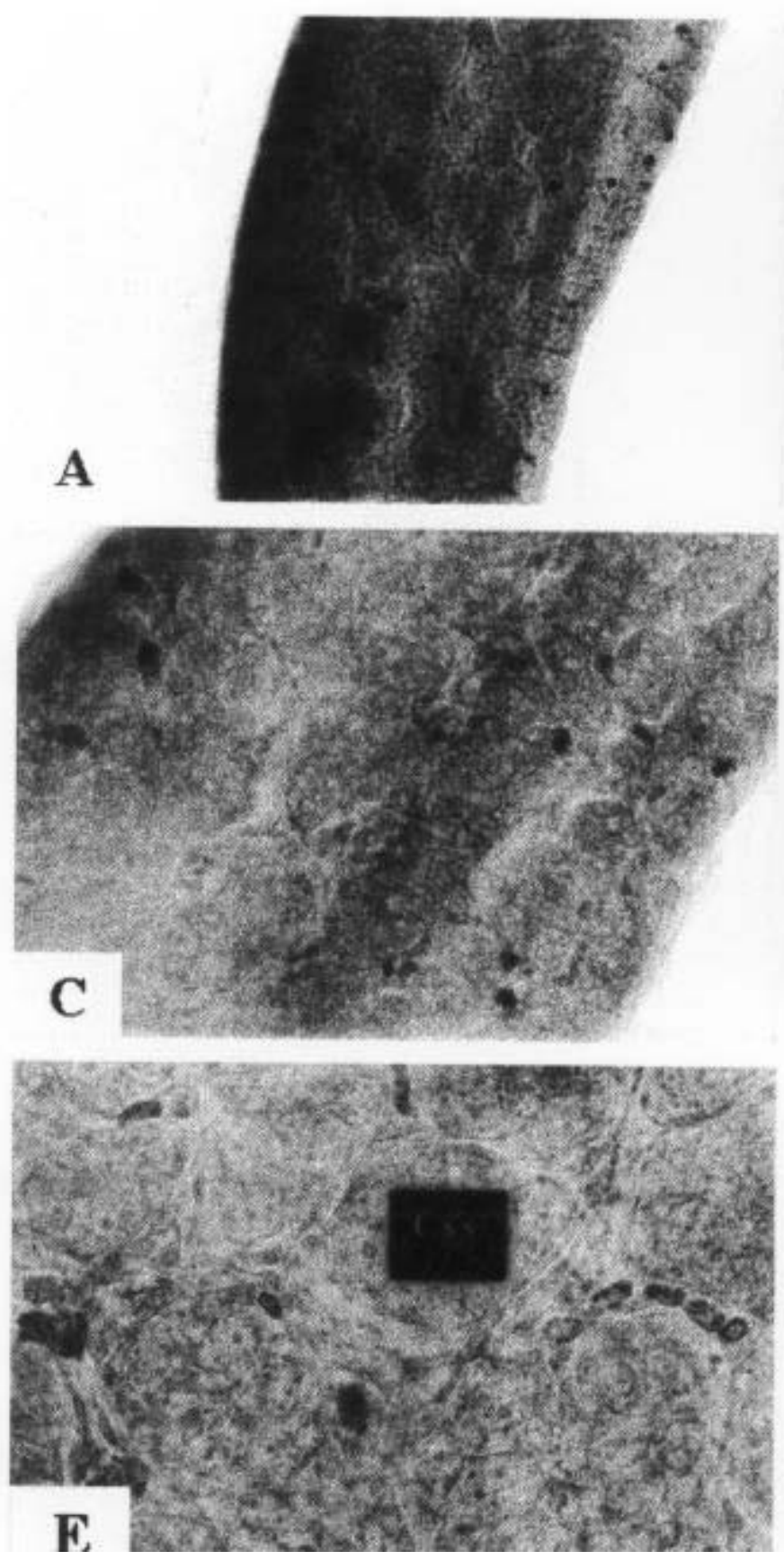

observed oocytes at the perinucleolar stage inside the ovaries (Figure 4B). A magnification of $200 \times$ (Figure $4 C$ and $4 D$ ) allowed a better definition of what was seen at $100 \mathrm{x}$. At the magnification of $400 \mathrm{x}$ the cysts inside the testis were well defined and spermatogonia and spermatocytes could clearly be observed (Figure $4 \mathrm{E})$. In the ovaries at $400 \mathrm{x}$ it was further confirmed the observations at 100 and $200 \times$ (Figure 4F).
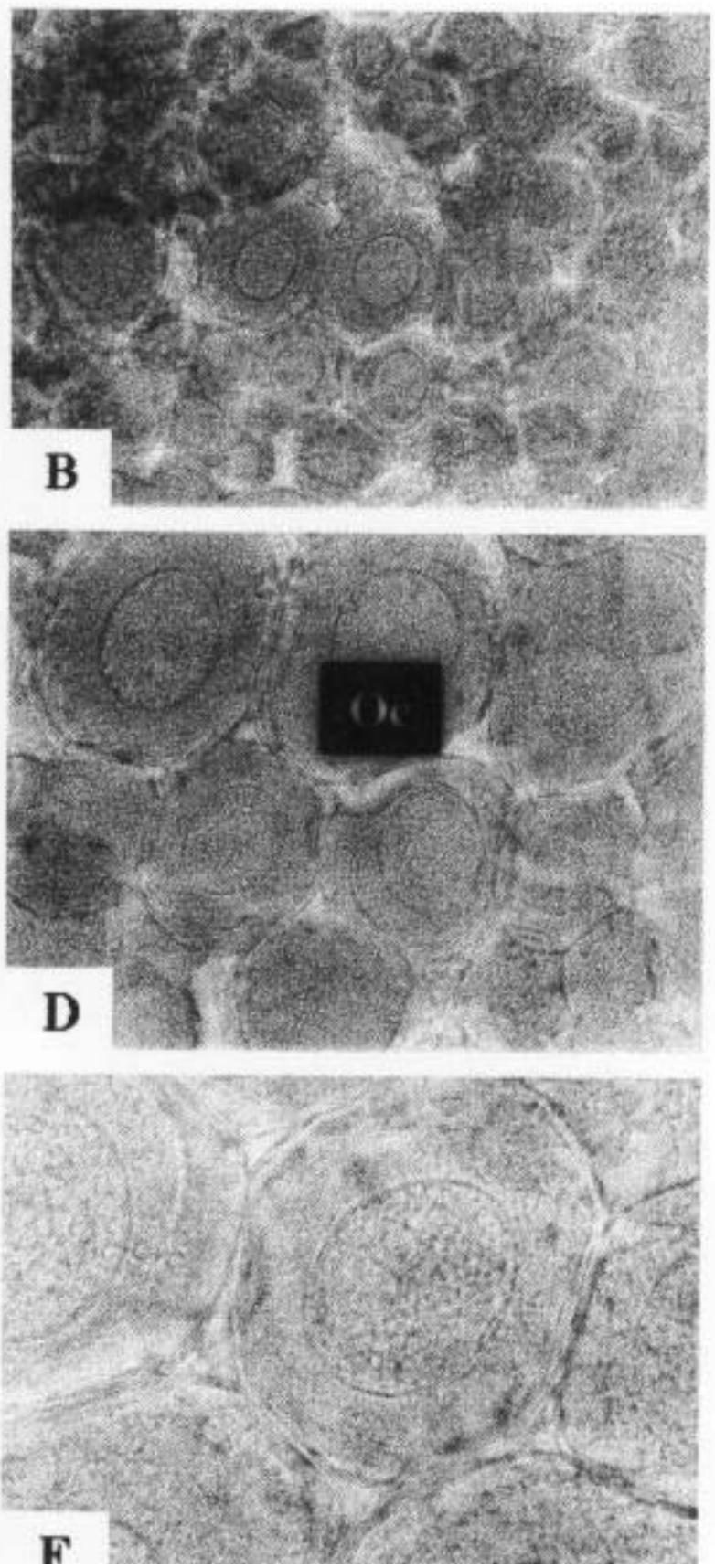

Figure 4 - Phenotypic sex of Nile tilapia fry using the aceto-carmine technique. Male and female gonads at $100 \times$ (A and B), $200 \times(C$ and D) and $400 \mathrm{x}$ (E and F). Cys, cysts; Oc, oocytes. 


\section{DISCUSSION}

The macroscopic technique (Method 1) proved to be an adequate auxiliary technique for sexing Nile tilapia above $0.50 \mathrm{~g}$. However, it does not allow defining differences between sexes based on cellular structures, which may cause some misinterpretation when just macroscopic sexing is used.

The validation of the squash technique (Method 2) through histology demonstrated that Nile tilapia fry above $0.50 \mathrm{~g}$ could be efficiently sexed by this method. The aceto-carmine method developed by GUERRERO \& SHELTON (1974) for sexing tilapia aurea (Oreochromis aureus) and bluegill (Lepomis macrochirus) has been used without previous validation for sexing tilapia (VARADARAJ, 1989 and VARADARAJ \& PANDIAN, 1991). A technique developed for staining chromosomes in squash of plant materials has also been used for sexing Nile tilapia (GALE $\boldsymbol{e} t$ al., 1999).

The criteria used in this study to define male and female gonads were more specific than those used by GUERRERO \& SHELTON (1974). Furthermore the stained gonads were sexed (Method 2) under a compound microscope with the use of magnifications ranging from $100 \mathrm{x}$ to $400 \mathrm{x}$. Since both gonads were removed intact from the abdominal cavity, it was possible to observe the gonads longitudinally in both sexes, and if further investigation was necessary it was possible to proceed to histological analysis. The squash technique also allows the identification of intersex individuals in Nile tilapia, mainly by the presence of oocytes scattered among testicular tissue (AFONSO et al., 2001). Similarly, VARADARAJ (1989) identified intersex Oreochromis mossambicus with use of the aceto-carmine squash technique (GUERRERO \& SHELTON, 1974). Reliable sexing, where morphological and cellular distinctions between sexes, could be made was possible with fish heavier than $0.5 \mathrm{~g}$ (above $32 \mathrm{~mm}$ and 45-47 DAH).

In summary, the method described for sexing Nile tilapia staining the gonadal tissue and examining it microscopically proved to be effective. Furthermore, the method allows for a fast analysis of sex proportion and also demands less material, labour and time than histological procedures. This technique may be used either as a tool for determining the sex ratio in sex control studies or by producers for checking the success of the sex reversal process.

\section{ACKNOWLEDGMENTS}

The authors thank the staff of Aquaculture Laboratory UFRGS, Dr. M.T. Schifino-Wittmann, as well as the staff of Pathos Laboratory. We also would like to thank Dr. Edward M. Donaldson and Jack Smith for the scientific revision of this manuscript. This research was supported by FAPERGS grant: 98/1555.7 and CNPQ Research Award 520066/98-7 to Luis Afonso.

\section{REFERENCES}

AFONSO, L.O.B.; LEBOUTE, E.M. Método para a sexagem visual de alevinos de tilapia nilotica (Oreochromis niloticus). In: ENCONTRO RIOGRANDENSE DE TECNICOS EM AQUiCUlTURA, 4, 1993, Porto Alegre, RS, Brasil, Anais... Porto Alegre \; UFRGS, 1993. p.100-103.

AFONSO, L.O.B.; GUDDE, D.H.; LEBOUTE, E.M. Metodo para incubacao artificial de ovos de tilapia nilotica (Oreochromis niloticus). Revista da Sociedade Brasileira de Zootecnia, Brasil, v.22, p.502-505, 1993.

AFONSO, L.O.B.; WASSERMANN, G.J.; OLIVEIRA, R.T. Sex reversal in Nile tilapia (Oreochromis niloticus) using a nonsteroidal aromatase inhibitor. Journal of Experimental Zoology, New York, v.290, p.177-181, 2001.

DONALDSON, E.M.; DEVLIN, R.H.; PIFERRER, F. Hormone and sex control in fish with emphasis on salmon. Asian Fisheries Society, Manila, v.9, p.1-8, 1996.

GALE, W.L.; FITZPATRICK, M.S.; LUCERO, M., et al. Masculinization of Nile tilapia (Oreochromis niloticus) by immersion in androgens. Aquaculture, Amsterdam, v.178, p.349-357, 1999.

GUERRERO, R.D; SHELTON W.L. An aceto-carmine squash technique for sexing juvenile fishes. The Progressive FishCulturist, v.36, p.56, 1974.

PANDIAN, T.J.; SHEELA, S.G. Hormonal induction of sex reversal in fish. Aquaculture, Amsterdam, v.138, p.1-22, 1995.

SHELTON, W.L.; GUERRERO, D.R.; MACIAS, J.L. Factors affecting androgens sex reversal of tilapia aurea. Aquaculture, Amsterdam, v.25, p.59-65, 1981.

VARADARAJ, K. Feminization of Oreochromis mossambicus by the administration of Diethylstilbestrol. Aquaculture, Amsterdam, v.80, p.337-341, 1989.

VARADARAJ, K.; PANDIAN T.J. Masculinization of Oreochromis mossambicus by administration of $17 \alpha$-methyl5 -androsten-3 $\beta$-diol through rearing water. Current Science, Columbus, v.56, p.412-413.1987.

VARADARAJ, K; PANDIAN T.J. Effect of solubilizing $17 \alpha-$ ethynyltestosterone in three different solvents on sex reversal of Mozambique tilapia. Progressive Fish-Culturist, v.53, p.67-71, 1991 . 